\title{
Productivity Enhancing Sustainable Human Care and Knowledge Management Practices in Sri Lankan Tea Industry
}

\author{
A T Gamage \\ Deputy General Manager \\ Kelani Valley Plantations PLC, Hayleys Plantations Sector \\ Sri Lanka \\ W.P.R Wickramaratne, PhD \\ Senior Lecturer in HRM \\ Department of HRM, Faculty of Management \\ University of Peradeniya \\ Sri Lanka
}

\begin{abstract}
The aim of this paper was to propose human care practices (HCPS) and knowledge management practices (KMPs) as sustainable human resource management practices (SHRMPs) that enhance the worker productivity in the tea industry in Sri Lanka. Un-structured interviews of 15 senior level managers of well performing tea estates in Sri Lanka reported HCPs and KMPs as sustainable HR practices, which provide a strong foundation for consistent enhancement of worker productivity in tea industry. These outcomes are based on the premise of Psychological Contract (Argyris, 1960; Rousseau, Tomprou\& Montes, 2013; Savarimuthu and Rachael, 2017) and Social Exchange (Blau, 1964; Redmond, $2015)$ theories. The theoretical and policy implications are also discussed.
\end{abstract}

Keywords: sustainable, human care practices, knowledge management practices, worker productivity, plantation industry, Sri Lanka.

\section{Introduction}

The tea industry has been a very strategic and integral sector in Sri Lanka's socio-economic and ethno cultural milieu for over 150 years from its inception. That is, this sector has played a prominent role by being the backbone and a permanent component of the economy of Sri Lanka. Sri Lanka accounts for 17\% of the global exports by being of the biggest producers and exporters of tea in the world (Bolton, 2016). The tea industry is one of the major agro-industrial sectors in Sri Lanka and it generates $65 \%$ of export agriculture revenue and contributes approximately $4.2 \%$ of island's GDP (Central Bank, 2015). The role of tea within the plantation industry is also significant, by being the key contributor to overall plantation industry performance and a global brand image well over other plantation crops such as rubber and coconut.

The declining productivity of the Sri Lankan tea industry is one of the key issues (Kelegama, 2010; Munasinghe, Deraniyagala, Dassanayake and Karunarathna, 2017). This has resulted in the lowest productivity amongst tea producing countries. Currently, the cost of tea production in Sri Lanka is around US\$ 1.75 per $\mathrm{kg}$ which is above that of Bangladesh (U\$ 1.35) and India (U\$ 1.25) whereas Kenya (U\$ 1.00) and Vietnam (U\$ 0.75) report the lowest (FAO, 2015).

Despite the fact that there has been a rapid growth in the non-agricultural sector and lack of dynamism in the tea industry (Wijayasiri, Arunatilake \& Kelegama, 2018) as well as the declining productivity (Kelegama, 2010; Munasinghe et al., 2017), the tea industry still remains as a vital sector of the Sri Lankan economy in terms of the national output, employment and net foreign earnings. The tea industry is the most labour intensive national industry with direct employment of 700,000 people which account for $10 \%$ of the national labour force of 8 Million (Central Bank of Sri Lanka, 2014). Kelegama (2010) stated that the high cost of labour is one major reason for the low productivity in tea plantation sector. Therefore, this increasing cost of production along with declining international prices has resulted in serious economic, social and environmental consequences. For example due to lower profit margins, tea manufacturers are forced to cut back monitory and non-financial benefits for workers, investments into modern and efficient technology and agronomic \& agricultural practices. This would ultimately impact on the quality of tea produced and, in the long run, would affect all the actors in the supply chain (Munasinghe et al., 2007). 
As shown in Figure 1, the cost of labour alone accounts for $65-70 \%$ of the total cost of production per Kilogram of made tea. The productivity of labour, particularly the harvesters, has a very high correlation to the total productivity and profitability of tea plantations. Tea harvesting continues to be very highly labour intensive regardless of the size of the operation and any diminution of productivity by harvesters exacerbates the tenuous relationship of the industry's sensitivity to profits (Sivaram, 2000).

Figure 1: The Composition of the Cost of Tea Production

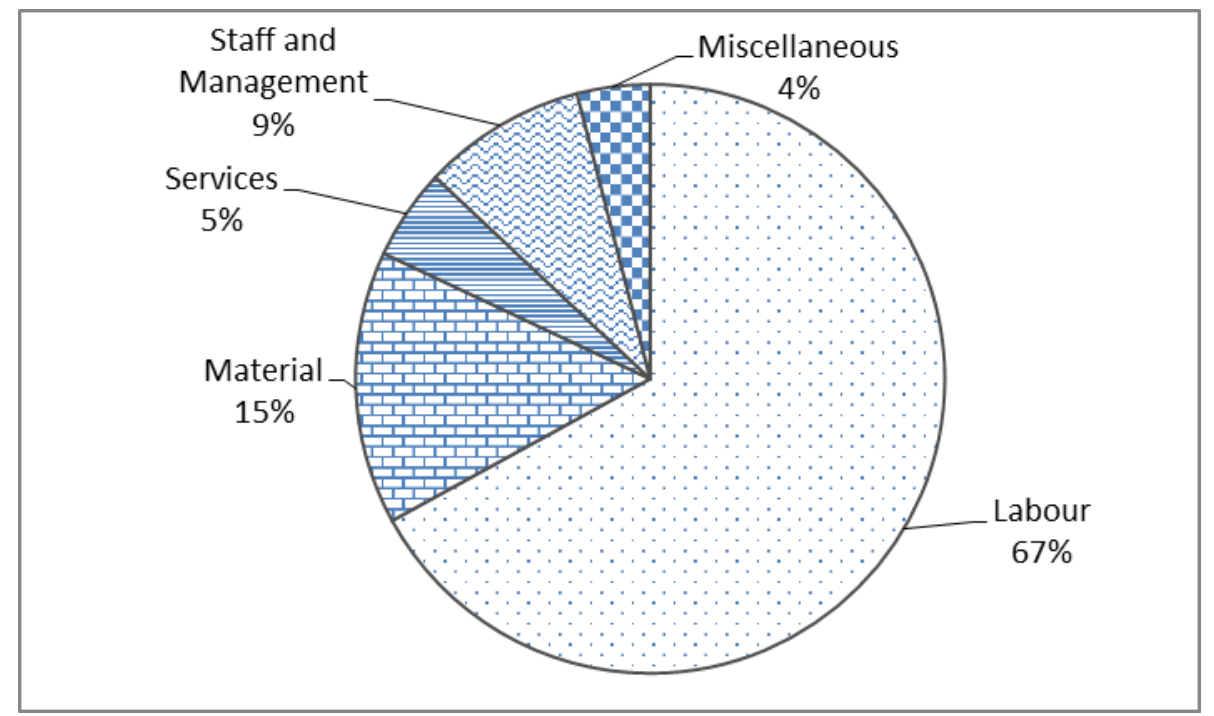

Source: Sri Lanka Tea Board Statistical Bulletin, 2010

The shortage of skilled workers, the increase in the resident "non-workers" within the estate population and the depletion of the quality of work life of the estate workers have contributed to the low productivity levels that prevail in the tea estates of Sri Lanka. These present critical issues within the tea estates have created several gaps in management systems, practices and civic rights of the work force. Kurihara (2007, p. 128) claims that "it is apparent that the conventional plantation management system has not been adequately equipped for serving the estate residents for basic social services since the establishment of the plantation sector in the $19^{\text {th }}$ century. The plantation system's holistic control over the estate resident's life does not respond to the resident's needs that have become more serious than ever. For example, Bawa and Jantan (2005) identified that there is a significant negative relationship between HR practices and voluntary turnover in plantation industry. They further elaborated on the propensity of employees to quit their jobs when working conditions are not conducive.

As discussed earlier, it is well accepted that the tea plantation industry has been the most labour intensive industry in Sri Lanka and therefore, reducing the cost of labour will increase profit margins which will enable organizations to invest more on the welfare of their employees. On the other hand, Sri Lanka poverty level in plantation sector exceeds the national average, with 30\% living below the poverty line (Yogaratnam, 2010). The actual situation in most of the cases in tea plantation work life is that the working conditions of plantation workers are often poor, with low wages, low job opportunities, lack of income security, discrimination based on ethnic and gender lines, lack of protective measures with inadequate basic facilities such as drinking water, food, sanitary facilities and housing. Yogaratnam (2010) explains that, there is no possibility for tea plantation workers to improve working conditions which has been linked with the ineffective trade unions in which, they are not really representing the ordinary work force due to uncontrollable political pressure.

In this context of declining productivity and lack of best management practices, it is necessary to open up different approaches as alternatives to increase the worker productivity. Some previous studies have highlighted that different human resource approaches to uplift the workers' social status and resolving social obligations related to the social well-being of workers will contribute positively on increasing productivity levels from the existing levels (Wickramasinghe and Cameron, 2003; Kodithuwakku and Priyanath, 2007; Dishanka and Ikemoto, 2013; Redmond 2015; Savarimuthu and Rachael, 2017).

In sum, increasing the human productivity has become a vital need to gain competitive advantage over the rising competition and cost in tea plantation industry. The most strategic way forward to fulfill this requirement is to understand and value the knowledge levels of the work-force and creating cultural changes to the existing human resource framework. 
This in return will enhance their present status of work lives as well as personal lives, by practicing human care best practices and allowing them to exchange their expertise areas for sustainable productivity enhancement in the industry which is the most lacking component at the moment. Based on these research deficiencies in the plantation sector, the main purpose of this study was to propose sustainable human care and knowledge management practices applicable to the tea industry, which definitely will have significant impact on worker productivity while enhancing the worker quality of life as well as quality of work-life.

\section{A Brief History Of The Tea Industry In Sri Lanka}

Plantation sector in Sri Lanka began way back in early 1880s' with planting perennial crops such as coffee, tea and rubber. The commercial planting of tea was introduced to Sri Lanka by a Scotsman, James Taylor in 1867, in a 19 acre land at Loolecondera Estate, Hewaheta with the intention of testing tea as a possible alternative crop for coffee. This was because coffee was facing a leaf rust epidemic and was destroying the coffee plantations in the country (Sivapalan, Kulasegaram \& Kathiravetpillai, 1986). Wal (2008) claimed that tea produced in the country is popular as "Ceylon Tea" which ranks among the best available tea in the international trade. Sri Lankan tea industry is 150 years old which accounts as the world's third largest Black Tea producer with a $17 \%$ share in the world's tea export market as the world's best quality tea and earns $2^{\text {nd }}$ largest net foreign exchange income for Sri Lanka which was recorded as US\$ 1.5 Billion in 2014 (Central bank of Sri Lanka, 2014).For more than a century, Sri Lanka's tea industry has been the backbone of the island's economy contributing $40 \%$ of export revenue and $30 \%$ of the agricultural labor force. During this period the country's development activities and the socio-economic progress have been closely linked with the tea industry (Kodithuwakku and Priyanath, 2007). Even though the tea industry was the main employment provider more than a century, the main source of foreign exchange and the main source of government revenue, recent statistics suggest that the contribution of the tea industry towards the Sri Lankan economy is gradually declining (Thushara, 2015).

\section{Review of Literature}

\subsection{Human care practices}

Productivity is concerned with the process of achieving the ultimate goals of the organization in terms of the processing input to reflect the expected outcome of the system (Armstrong, 2010). In respect of tea plantations, there are major productivity indicators which are frequently used for measuring performance in the industry such as worker output per day (intake per harvester) and total quantity harvested which refers to yield per hectare (Sivaram, 2000). Therefore, increasing harvester productivity means increasing the quantity of green leaf harvested per day.

The care for workers' basic human needs plays a significant role to develop a "plantation family" as a social unit within the plantation community and to enhance the productivity indicators as well as to build up a strategic relationship between management and employees as major partners in the tea plantation community. That is, when individuals receive a benefit, they may experience a state of discomfort due to a sense of indebtedness and thus, force them to reciprocate the benefit in order to restore the equilibrium of the interpersonal relationship (Jones, 1981; Roloff ,1987; Rajaurai, 2015; Redmond, 2015; Savarimuthu and Rachael, 2017). However, increasing the workforce commitment is crucial on sustainable productivity improvement patterns specifically in tea plantations being a highly labour intensive industry. This fact was highlighted in a study of Rusbult (1988) which states that people stayed in dissatisfying relationships because of their level of investment or lack of alternatives. This was further emphasized by Redmond (2015) who found that the person's commitment to the relationship is increased by the investment, rewards and lack of alternatives. In support of these arguments, a recent study claimed that the psychological contract concerns mutual obligations between employer and employee, in which both parties invest in their relationship in different means with the expectation of a positive outcome for both parties as well as this mutual agreement include elements such as values, beliefs, expectations and aspirations of both the employee and employer (Savarimuthu and Rachael, 2017).

Kodithuwakku and Priyanath (2007) revealed that the financial benefits i.e. salary, allowances, salary increments, overtime and loan facilities, non-financial facilities, welfare facilities like housing, education, health, daycare centers, transport, electricity etc. provided by the management of firms for laborers are highly effective in improving the labor productivity through the increase of labor satisfaction. According to Rajadurai (2015) factors such as demographics, personal life style and socio economic factors had more effect on individual productivity than management and agronomic factors. Sivaram (2000) highlighted the impact of socio economic and health factors on the performance of women Tea workers in South India. In order to increase the present levels of worker productivity indicators frequently used in tea plantations, extent of using best human resource functions inculcating worker sensitive human care practices will also have a significant impact. 
These findings were supported by subsequent studies (Koukoli, Vlachonikolis\&Philalithis, 2002; Kurian, 2010). Koukoli, Vlachonikolis and Philalithis (2002) claimed that socio demographic factors are important as physical health variables affecting a person's ability to function normally in their everyday life. Socio demographic variables included; gender, age, level of education, employment status, profession, marital status, total number of persons living in the house and living arrangements. They further indicated that nutritional status affects worker outcomes, particularly productivity indicators. In support of these arguments, Kurian (2010) stated that physical quality of life focuses on people's welfare, their living and working conditions, their attitudes towards work and recreation. The factors that are taken into account for physical quality of life of women workers in tea plantations are consumption patterns, health standards, educational status, working conditions, living conditions and socio cultural activities. These empirical justifications lead to the study's first research question.

RQ1- What are the human care practices that enhance worker productivity of tea plantation industry in Sri Lanka?

\subsection{Knowledge management practices}

Just after liberalization of Sri Lankan economy in 1977, the labor productivity in tea plantation sector improved due to the improvement of labor satisfaction with the privatization of tea estates, strict management and application of new techniques in the private companies (Kalegama, 2010). Prior studies suggest that, industry's investment on developing employees' skills creates a productive workforce (Patterson, Warr and West, 2004; Dishanka and Ikemoto, 2013). More importantly, knowledge management practices lead to higher productivity of employees in tea industry (Sharpe, 2014 and Dishanka \& Ikemoto, 2013). Further, Sivaram (2000) explained that, a combination of better skills, improved knowledge, positive attitudes and human care support will go a long way to upgrade an average productive worker in to a top performer. These empirical justifications lead to the study's second research question.

$\boldsymbol{R Q} 2$ 2- What are the knowledge management practices that enhance worker productivity of tea plantation industry in Sri Lanka?

\section{Methodology}

\subsection{Method and procedure of data collection}

The method of data collection used in order to address the above stated two research questions was face-to-face interviews, coupled with interviews over the telephone based on an un-structured questionnaire in order to identify and group the best human care practices, and also to identify and cluster the most appropriate Knowledge Management practices that enhance the worker productivity in tea plantation industry in Sri Lanka. The sample included 15 Senior Managers who are presently working in well-established tea plantation firms and the selection was done through simple random sampling. This process was purely based on their experience in the tea industry. The reliability of the information was assured by replicating the questions in the questionnaire for same information using various patterns and such information was supported with the findings from multiple sources such as publications, industry related research papers and participatory observations. Average duration of each interview was 30 minutes and additional 15 minutes per participant were given to elaborate their open views and further clarifications.

The questionnaire was divided in to two main sections, part one for general information about the participants such as their experience, age and designation. The questions in part two were tabulated as open ended questions within the predetermined structure for clustering human care practices and knowledge management practices which are comparatively important to enhance the worker productivity. The selected senior level plantation managers were given an opportunity to prioritize human care and knowledge management practices according to the relative importance. See appendix for the detailed questionnaire.

The human care practices were clustered during the questionnaire development stage based on the pre-determined categories by considering the appropriate practical applications in the industry. Also, the knowledge management practices were grouped according to the steps involved in process of knowledge management cycle (Evans, Dalkir, \&Bidian, 2014). The human care and knowledge management practices for the questionnaire were also based on the findings of previous studies (Evans et al., 2014; Evans \& Ali, 2013; Dalkir, 2011).

\subsection{Theoretical framework}

The productivity level of the worker has direct relationship with sustainable HR practices with a long-term focus, which is greatly impacted by human care best practices and knowledge management practices. The strength of the process of enhancing and sustaining the worker productivity levels in tea plantations is the key foundation for the proposed human resource management model. This is further related to the know-how of their own job performing areas or knowledge related to the job specifications in plantation communities, and the level of sharing this knowledge for the betterment of the industry's futuristic perspective. 
Aiming towards long-term sustainability of the industry and gaining competitive advantage while facing the local and global challenges is vital in an environment where there is a competition for productivity and managing knowledge for the development of the industry. Therefore, the ultimate objective should be sustainable development of the tea plantation industry through a sound and competent human resource base. The proposed theoretical model is expected to make a unique contribution by incorporating human care practices and knowledge management practices in enhancing employee productivity.

The proposed model is based on the premise of Psychological Contract (Argyris, 1960) and Social Exchange (Blau, 1964) Theories. The psychological contract, introduced by Argyris, suggests that the employment relationship goes beyond the formal economic employment contract. The psychological contract is defined by Rousseau $(1989$, p.390) as "an individual's beliefs regarding reciprocal obligations set in the context of the employer/employee relationship." The psychological contract emerges when the employee believes that "a promise has been made and a consideration offered in exchange for it, binding the parties to some set of reciprocal obligations" (Rousseau 1989, p. 123).Rousseau, 2004, further argued that, psychological contract in organizations motivates workers to fulfill commitments made to employers when workers are confident that employers will reciprocate and fulfill their end of the bargain. Employers in turn have their own psychological contracts with workers, depending upon their individual competence, trustworthiness and Sarantinos, 2007 added that, this is important to the firm's objectives of increasing overall performance. As explained by Blau (1964), social exchanges involve unspecified obligations when one person does another a favour, there is an expectation of some future return. Employees tend to take a long-term approach to social exchange relationships at work, with the pattern of reciprocity over time determining the perceived balance in exchanges (Blau, 1964; Rousseau 1989; Redmond, 2015). Authors strongly argued that the strength of the relationship for exchanging benefits between employers and employees described the relative importance in terms of strategic balance between rewards and the cost. This fact was well supported with the findings of Levine and Kim (2010, p. 306) and they described the process as applied to relationships in working environment that, people in relationships have a metaphorical spreadsheet in which relational credits and debits are tabulated, and future profits are forecasted. People are satisfied with their relationships when the rewards exceed the costs, and they continue in those relationships where investments lead to projected future profit. By applying these two theories it's expected that the productivity of tea plantation employees is enhanced by human care and knowledge management practices since workers develop a sense of an obligation to reciprocate by increasing their productivity as they receive human care and knowledge management practices. Figure 2 presents the conceptual framework of the study.

Figure 2: Conceptual Framework

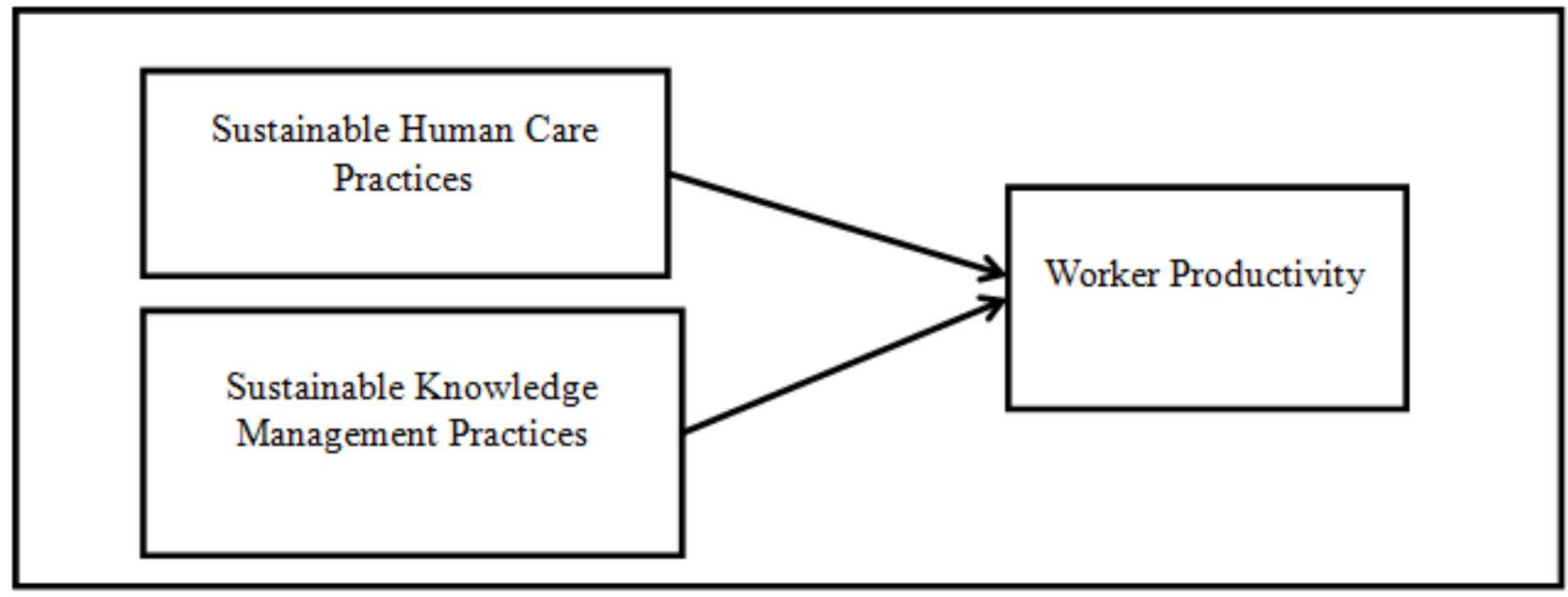

Source: Author Developed

\section{Findings}

The best human care and knowledge management practices identified through the interviews were grouped according to the pre-determined structure of best practices categories considering the researcher's experience in the plantation industry. The following best practices were identified under the main criteria of human care practices and knowledge management practices based on the managers' responses to the unstructured interviews. The analysis of interview responses of senior level plantation managers revealed that the identified best human care practices and knowledge management practices directly influence to enhance the worker productivity levels of tea industry in Sri Lanka. 
Therefore, the HRM model proposed for tea plantation industry, explained that the identified sustainable human care practices and knowledge management practices have a direct influence in improving worker productivity. The sustainable human care practices and knowledge management practices identified in this study are presented in the following table (Table 1: Sustainable human care and knowledge management practices).

Table 1: Sustainable human care and knowledge management practices



Source: Interview Data. 


\section{Discussion}

The findings of this study were supported with the theories and models developed through various researches. Szulanski (1996) highlighted that, it might be profitable to devote scarce resources and managerial attention to develop the learning capacities of organizational units, foster closer relationships between organizational units, and systematically understand and communicate practices such as knowledge management practices which impact more on the worker productivity levels than just merely paying incentives. Omotayo (2015) pointed out that without adequate care about how knowledge is managed, organizations will not be operating optimally and this will result in the ineffective and inefficient creation and delivery of products and services leading to lack of quality in work-life, which is what ultimately leads to the demise of the organization due to poor productivity levels. The relationship between sustainable HR practices and worker productivity is further elaborated in psychological contract and social exchange theories. That is, plantation workers receive various types of support by way of human resource management and knowledge management practices in turn workers enhance their productivity to reciprocate for the support they received. Implementing best HR practices will increase the level of employee engagement, which is considered to be a vital aspect behind the efficiency of the employees and thereby productivity of the organization (Lodha\& Pathak, 2017). Moreover, they further elaborated that, the relationship between psychological contract and the employee engagement by analyzing the several factors from both the variables towards worker productivity. Employee engagement initiatives as sustainable HR practices adopted in an organization, have been linked to their productivity (Irvine, 2009; Masson, Royal, Agnew \& Fine, 2008). Empirical studies have also indicated that the employee engagement is associated with psychological contracts (Bal, Kooij, \&DeJong, 2013; Chang, Hsu, Liou, \& Tsai, 2013). Rousseau (1989) defined psychological contracts as the beliefs that are held by an individual regarding what they owe the organization, and what the organization owes them. Thus, fulfillment of employer promises, obligations, and commitments increases employee engagement (Coffman \& Gonzalez-Molina, 2002; Bal et al., 2013; Chang et al., 2013). Chang et al. (2013) and Bal et al. (2013) empirically demonstrated that an increase in psychological contract fulfillment is related to an increase in employee engagement and ultimately the enhanced employee productivity.

\subsection{Policy implications}

This research provides some important implications to policy makers in the tea industry. That is, the employees should be provided with human care practices in areas such as living environment (e.g. housing facilities, pure drinking water, childcare facilities, electricity and adequate road access), health and nutrition (e.g. medical care facilities including caring for mothers and children, vaccination, health awareness and healthcare training), safety and protection (e.g. occupation safety and protection policies, providing necessary safety equipment and implementing occupation safety standards), employee capacity building (e.g. micro finance facilities for small business, training and awareness on savings and cash handling and motivation to initiate own family business), education and development (e.g. facilities and support for children's education, employment opportunities for children and succession management for allowing employees enter into managerial positions) and youth empowerment (e.g. training and guiding youth in plantation for skill development and vocational training, facilities and guidance for higher education and to upgrade language and IT skills).Policy makers should also implement best knowledge management practices in areas such as collection and capturing (e.g. transparent communication tools and mixing new technology and IT for capturing and processing information that facilitate speedy decision making), classify, organize and storing information (e.g. adequate use of new technology, and Implementing methods of sharing the best practices and advanced knowledge throughout the entire human resource segment), knowledge sharing (e.g. introducing the methods of self-development, using IT to speedy sharing systems of knowledge acquired such as intra-net walls, implementing knowledge competencies in an on-line system and introducing 'learning by example'- Initiated from estate level senior leadership), knowledge access and use (e.g. introducing 'dash board systems' for frequent reviews and monitoring, system to be introduced to record systematically,

The 'specialized knowledge' gained over the years by experience and system to introduce to inculcate this knowledge in to management decision making process wherever possible and applicable), value creation (e.g. Develop annual training calendar based on the needs and to match with organizations goals and objectives, exchange the internal trainers from estate to estate and offering more training opportunities on business innovations and development) and sustainability (e.g. Promoting opportunities for higher studies to gain technical competencies match with new and modern scientific knowledge, process of building-up more relationships with higher education institutes such as universities, altering the recruitment process to recruit more educated and talented youth and developing a talent pool and to link it with succession plan effectively). Once these human care practices and knowledge management practices are implemented, the employees' quality of work life and the quality of life would also be increased. The ultimate outcome would be increased productivity of employees. 


\subsection{Limitations and directions for future research}

These findings are based on a qualitative study of fifteen senior managers of the tea plantation industry in Sri Lanka. Therefore, the findings cannot be generalized to the whole tea plantation industry. Consequently, these research outcomes should be further investigated by conducting a survey based on a larger sample so that the findings could be generalized to the tea industry. Furthermore, the current findings represent only the views of senior managers. Therefore, the same study should be conducted based on a sample that represents other employees such as middle level managers, floor level employees as well as business owners. The same study should be replicated in other tea growing countries to generalize the findings to the international context since the cultural and institutional context in Sri Lanka is different from that of other countries.

\section{Conclusion}

The model proposed by this study as a sustainable HRM model for tea industry, stressed that the best human care practices and knowledge management practices are factors that determine the worker productivity of tea estate workers. This model is a unique addition to the contemporary HRM models practiced in various industries which focuses on adding more value towards enhancing worker productivity levels in the tea industry. The total HRM practices that should apply in the tea industry should go beyond the conventional HR practices and focus more on the best human care practices and knowledge management practices which contribute to enhance the levels of more critical productivity indicators.

\section{References}

Argyris, C. (1960). Understanding organizational behavior. American Political Science Review, 54(3).

Armstrong, S. (2010). Handbook of Human-resource Management Practice (11th ed.). Human Resource Management International Digest, 18(4), 48-59 doi:https://doi.org/10.1108/hrmid.2010.04418dae.001

Bal, P., Kooij, D., \&DeJong, S. (2013). How do developmental and accommodative HRM enhance employee engagement and commitment? The role of psychological contract and SOC strategies. Journal of Management Studies, 50(4)546-572.

Bandara, R.W.T.M. (1996). The present status of ecological capital management in the Tea Plantation sector in Sri Lanka. An exposition of the concept with illustrative case studies. Colombo: University of Colombo.

Barr, A., \&Serneels, P. (2008). Reciprocity in the workplace. England: University of Oxford.

Bawa, M.A., \&Jantan M. (2005). Human Resource practices as determinants of employee turnover: An empirical investigation. Asian Academy of Management Journal, 10(02), 69-80.

Blau, P.M. (1964). Exchange and power in social life. Social Forces, 44(1), 128-129. Retrieved from https://doi.org/10.2307/2574842.

Bolton, D. (2016). Global Tea Production (2015). http://worldteanews. com/news/global-tea-production-2015.

Central Bank of Sri Lanka. (2014). Annual Report. Colombo: Central Bank of Sri Lanka.

Central Bank of Sri Lanka. (2016). Annual Report. Colombo: Central Bank of Sri Lanka.

Central Bank of Sri Lanka (2015). Annual Report: Central Bank of Sri Lanka.

Chadwick-Jones, J.K. (1981). Renegotiating absence levels. Journal of Organizational Behavior, 2(4), 255-266.

Chang, H.-T., Hsu, H.-M., Liou, J.-W., \& Tsai, C.-T. (2013). Psychological contracts and innovative behavior: A moderated path analysis of work engagement and job resources. Journal of Applied Psychology, 43(10) 21202135.

Coffman, C., \& Gonzalez-Molina, G. (2002). Follow This Path: How the world's greatest organizations drive growth by unleashing human potential. New York: Warner Books.

Dalkir, K. (2011) Knowledge management in theory and practice, 2nd edition, Cambridge, MA: Massachusetts Institute of Technology

Evans, M., Dalkir, K., \&Bidian, C. (2014). A holistic view of the knowledge life cycle: the knowledge management cycle (KMC) model. Electronic Journal of Knowledge Management, 12(2), 85-97.

Evans, M. M. and Ali, N. (2013) 'Bridging knowledge management life cycle theory and practice', International Conference on Intellectual Capital, Knowledge Management and Organisational Learning ICICKM 2013 Conference Proceedings, Washington, DC: Academic Conferences and Publishing International, pp. 156-165.

FAO 2015. World tea production and trade Current and future development by Kaison Chang, Trade and Markets Division. Food and Agriculture Organization, Rome, 2015.

Garbutt, D. (1979). Charles Babbage - pioneer of scientific operations research. The Accountant,7(2), 389-397.

International Labour Organization. (2000). World Labour Report 2000: Income security and social protection in a changing world, International Labour Office, Geneva. 
Irvine,D.(2009). Retrieved from Bloomberg Business Week: http://www.businessweek.com/bwdaily/dnflash/content/may2009/db2009058_952910.htm.

Kelegama, S. (2010). Productivity Decline in the Tea Plantations and a Possible Way Forward. Colombo: VijithaYapa Publications.

Kodithuwakku, S., \&Priyanath, H.M.S. (2007). Reasons for the improvement of labour productivity in Tea Plantations after privatization with special reference to the estate laborers in Tea Plantations after privatization with special reference to the estate laborers in Rathnapura district. Sabaragamuwa University Journal, 7(1), 37-47.

Koukoli, S.,Vlachonikolis, I.G. \&Philalithis, A.(2002). Socio- demographic factors and self- reported functional status: the significance of social support. BMC Health Services Research, 2(20), 27-49.

Kurihara, S. (2007). The estate plantation community in NuwaraEliya district of Sri Lanka: An introductory overview of social issues and poverty among residents living under the conventional plantation system. Yokohama Journal of Social Sciences, 15, 123-129.

Kurian, R. (1989). State capital and labour in the plantation industry in Sri Lanka. PhD thesis, University of Amsterdam, 1834-1894.

Lodha, D., \&Pathak, K. (2017). Effect of psychological contract on employee engagement. Journal of Researchers, l(1)6-9.

Masson, R., Royal, M., Agnew, T., \& Fine, S. (2008). Leveraging employee engagement: The practical implications. Industrial and Organizational Psychology, 1 (1)76-59.

Munasinghe, M., Deraniyagala, Y., Dassanayake, N., \&Karunarathna, H. (2017). Economic, social and environmental impacts and overall sustainability of the tea sector in Sri Lanka. Sustainable Production and Consumption, 12, 155-169.

Omotayo, F.O. (2015). Knowledge management as an important tool in organizational management: A review of literature. Library Philosophy and Practice (e-journal). 1238. Retrieved from http://digitalcommons.unl.edu/libphilprac/1238

Rajadurai, R. (2015). Determinants of Annual Productivity of Female Tea Harvesters in the Mid Country Regional Plantation Company Estates in Sri Lanka. Peradeniya: Post Graduate Institute of Agriculture.

Redmond, M.V. (2015). Face and politeness theories. English Technical Reports and White Papers. 2. Retrieved from http://lib.dr.iastate.edu/engl_reports/2.

Rich, B., LePine, J., \& Crawford, E. (2010). Job engagement: Antecedents and effects on job performance. Academy of Management Journal, 53(3), 617-635.

Roloff, J. (1987). Learning from multi-stakeholder networks: Issue-focused stakeholder, management. Journal of Business Ethics, 82(01), 233-250.

Rousseau, D. (1989). Psychological and implied contracts in organizations. Employee Responsibilities and Rights Journal, 2(2) $121-139$.

Rusbult, C.E. (1988). Impact of exchange variables on exit, voice, loyalty, and neglect: An integrative model of responses to declining job satisfaction. The Academy of Management Journal.31 (3), 599-627.

Saks, A.M. (2006). Antecedents and consequences of employee engagement. Journal of Managerial Psychology. 21(7) doi: 10.1108/02683940610690169.

Sivapalan, P., Kulasegaram, S., \&Kathirvetpillai, A. (1986). Hand Book on Tea. An overview of tea industry in Sri Lanka. In A. K. N. Zoysa (Eds.) (2008), Hand Book on Tea, Thalawakelle: Tea Research Institute of Sri Lanka.

Sivaram, B. (2000). Plantation Management in the New Millennium. Colombo: National Institute of Plantation Management.

Sri Lanka Tea Board. (2010). Annual Report. Colombo: Sri Lanka Tea Board.

Szulanski, G. (1996). Exploring internal stickiness: Impediments to the transfer of best practice within the firm. Strategic Management Journal, 17(02). 27-43.

Wal, S.V.D. (2008). Sustainability issues in the Tea Sector: A Comparative Analysis of Six Leading Producing Countries. Amsterdam, Netherlands: Centre for Research and Multinational Corporations.

Wijayasiri, J., Arunatilake, N. \&Kelegama, S. (2018). Sri Lanka Tea Industry Transition: 150 years and beyond. Colombo: Institute of Policy Studies of Sri Lanka.

Yogarathnam, N. (2010, May 18). Economics of scale ineffective in Lankan Tea Business. Daily News, p. 06. 